\title{
A természettudományos nevelés szakköri lehetőségei
}

\author{
Bauer Zita $^{1}$ és Papik Eszter ${ }^{2}$ \\ ${ }^{1}$ Eötvös Loránd Tudományegyetem Tanitó-és Óvóképző Kar, Természettudományi Tanszék \\ ${ }^{2}$ Budapest School
}

\begin{abstract}
Absztrakt
A természettudományok élményszerü tanításában, tanulásában kiemelkedő jelentőségű a kísérletezés módszere. Végzésük során a megismerési képességek fejlesztése mellett felkelti, illetve fokozza a tanulók természet és a természettudományok iránti érdeklődését, motiválja a tanulást, elősegíti a természettudományos-és a problémamegoldó gondolkodás fejlődését, alakítja munkavégzési szokásaikat, hozzájárul szociális kompetenciáik erősödéséhez. A tevékenységek a környezet megismerése mellett segítik az ökológiai- és rendszerszemlélet, valamint a környezet iránti pozitív attitűdök kialakulását, melyek a fenntarthatóság pedagógiai tartalmának megvalósulásában fontos alappilléreket jelentenek. Ezen célok elérésének fontos eszközei lehetnek a tanórán kívüli foglalkozások, így a szakkörök is. Tanulmányunkban egy, harmadik - negyedik osztályos gyermekekkel megvalósított szakkör tartalmának és eredményeinek ismertetésére vállalkozunk. A foglalkozások tematikáját, az elvégzett egyszerü, de látványos, a tanulók életkorának megfelelő, a gyerekek érdeklődését felkeltő tevékenységeket gyakorló és leendő pedagógusok számára egyaránt ajánljuk. Cikkünkkel nemcsak azok számára kívánunk segítséget nyújtani, akik szakköri foglalkozást terveznek, hiszen ezek a kísérletek jól beépíthetők a tanórák során megvalósított tevékenységek rendszerébe is.
\end{abstract}

Kulcsszavak: természettudományos nevelés, természettudományos gondolkodás, kísérlet, szakkör, attitűd

\section{A kísérletek jelentősége a természettudományos nevelésben}

Kísérletezés nélkül elképzelhetetlen a természettudományos gondolkodás alapozása az iskolában. A kísérlet az ismeretszerző módszerek legmagasabb szintű formája. A kísérletezéshez szükséges képességek fejlesztése során tovább fejlődnek az elemi természettudományos nevelésben már fejlesztett képességek (megfigyelö-, leíró-, azonosító-megkülönböztető képesség, mérési technika). Ez a módszer a legtöbb tanulónál felkelti, illetve fokozza a természet és a természettudományok iránti érdeklődést és kíváncsiságot, motiválja a tanulást. 
A természettudományok élményszerű tanításában, tanulásában kiemelkedő szerepet kell kapnia a kísérletezésnek. Ehhez szükséges, hogy a feldolgozandó témák, valamint a transzfer (tudásátadás, ismeretszerzés) életkorhoz illő, vonzó legyen. Alkalmazásuk közben a tanulók tények és képzetek szintjén élményszerű természettudományos tapasztalatok, ismeretek birtokába jutnak. Az önállóan, párban vagy csoportban végzett kísérletek bővítik a gyerekek anyagismeretét, mivel tapasztalhatóvá válnak a kölcsönhatásban megnyilvánuló tulajdonságok. A kísérletek elősegítik a természetben zajló folyamatok és jelenségek lényegének megértését, a fontos és szükséges tények megismerését, képzetek kialakulását, a természettudományos gondolkodás fejlődését.

A tevékenységek végzése során a diákok megtanulják az anyagok és eszközök balesetmentes használatát, miközben munkafegyelmük is fejlődik. Az egyszerü, hétköznapi eszközökkel végzett kísérletek során a gyermekek észrevehetik, hogy a természettudomány folyamatosan körülöttünk van. Előnyük továbbá, hogy ezeket az egyszerü eszközöket és anyagokat igénylő kísérleteket akár otthon is - természetesen szülöi felügyelettel - biztonságosan elvégezhetik (Papp, 2014).

Az iskolai kísérletezésnek sokféle szerepe lehet és ennek megfelelően több változatot is megkülönböztethetünk, például: látványkísérletek, demonstrációs kísérletek, modellkísérletek, jelenségbemutatás (Jenei et al., 2011).

Mivel a kísérletek végzése közben a tanulók egyre jobban megismerik a körülöttük lévő világ változatosságát, szépségét, rávilágítanak számos összefüggésére, fejlődik az ökológiai- és rendszerszemléletük, valamint problémamegoldó gondolkodásuk. A tevékenységek a környezet megismerése mellett segítik a vele való harmonikus és tudatos együttélést, a környezet iránti pozitív attitűdök kialakulását, melyek a fenntarthatóság pedagógiai tartalmának megvalósulásában fontos alappilléreket jelentenek.

\section{A szakkörök szerepe az alsó tagozatos természettudományos nevelésben}

A szakkörök hozzájárulnak az oktatói - nevelői munka színesebbé tételéhez. Ha egy iskolában több tanórán kívüli lehetőség, szakkör müködik, minden csoport egyéni színezetet, arculatot ad az iskola programjához, emellett a tehetséggondozást is szolgálhatják (például média szakkör, informatikai szakkör, dráma szakkör, könyvklub, kézmüves foglalkozás, tánc, foci, sakk szakkör).

Az iskolákban a közvetlen környezet megismerésére és az azzal való tudatos együttélésre nevelésben nem csupán a tanórák, hanem a tanórán kívüli tevékenységek is jó alapot szolgáltatnak. Kiváló szervezeti formát nyújtanak erre a szakkörök.

A szakkörök típusait tekintve a következők lehetnek:

1. Hagyományos értelemben vett szakkörök - az érdeklődés nélküli, közömbös tanulók érdeklődővé alakítása céljából szerveződnek. 
2. Orientációs szakkörök - célja: az érdeklődést és tehetséget mutató tanulók sajátos képességeinek feltárása.

3. Önképzőkörök, melyek a tehetséges tanulókat fejlesztik (Gaál \& Jászi, 2015).

Mivel az alsó tagozaton tudjuk megalapozni a természettudományos gondolkodást és a környezettudatosságra nevelést, a környezetismeret tantárgy csökkenő óraszámainak ellensúlyozására, kiegészítésére is szolgáló szakkörök jelentőségének meg kell erősödnie. Célja a tanulók szabadidejének hasznos eltöltése mellett környezetünk iránti érdeklődésük felkeltése, valamint elmélyítése, pozitív attitűdjük fejlesztése, természettudatos gondolkodásuk kialakításának segítése, önállóságuk, kreativitásuk növelése, készségeik, képességeik fejlesztése, illetve az ok-okozati viszonyok megfigyeltetése (Tóthné, 2015). A célok megvalósításához nagyban hozzájárul, hogy a szakkörök a tanulók aktív cselekvésére, a tapasztalatszerzés elsődlegességére építenek.

\section{A Kísérletezz velünk szakkör gyakorlati megvalósítása}

A 2019/2020-as tanévben harmadik - negyedik osztályos gyermekek számára indítottuk a környezetismeret tantárgyhoz kapcsolódóan a Kísérletezz velünk szakkört két heti rendszerességgel, Ez az időbeosztás előnyös volt mind a felkészülés miatt, mind az előzetesen közösen előkészített kísérletek tapasztalatainak megfigyelése szempontjából. Emellett munkaközösségünkkel egyeztetve úgy alakította ki a szakkörök sávjait, hogy a gyermekek akár - érdeklődésüknek megfelelően - többre is járhassanak.

A foglalkozások 90 perces időtartamban kerültek megvalósításra, kellő időt szánva az egyszerü, játékos tevékenységek elvégzésére, a tapasztalatok megbeszélésére, rögzítésére. A tervezés és lebonyolítás során az alábbi szempontokat vettük figyelembe:

1. A szakkör tematikáját úgy állítottuk össze, hogy egyrészt megfeleljen a NAT és a Kerettanterv tantárgyi követelményeinek, másrészt fejleszsze a természettudományos megismerési képességeket. Így elsősorban a harmadik és negyedik évfolyam tananyagára alapozva, azt kiegészítve terveztük meg a kísérleteket. A foglalkozások során fontosnak találtuk az egyszerű, de látványos, a tanulók életkorának megfelelő, a gyerekek érdeklődését felkeltő tevékenységeket.

2. Törekedtünk arra, hogy a tanulók a mindennapi életbe jól beépíthető és alkalmazható valós tapasztalatokat, adaptív tudáselemeket szerezzenek, ezért az őket körülvevő, hétköznapi és már ismert anyagokkal és technológiákkal találkozzanak, s így a kísérletek elvégzése és megértése során szerzett ismereteiket a napi életükhöz tudják kapcsolni. Olyan kísérleteket terveztünk tehát, melyeket otthon - szülöi felügyelet mellett - a gyerekek akár maguk is ki tudnak próbálni, el tudnak végezni.

3. A szakkör helyszínéül mi sem lehetett volna jobb választás, mint a kísérletezés sajátos és egyedi hangulatú helyszíne: a labor. A gyermekek 
számára a környezet már önmagában is motiváló volt. A tevékenységek végzése közben számos eszközt ismertek meg, így miközben jártasságot szereztek a kísérletezésben, megismerték az eszközök tulajdonságait, helyes, szabályos használatát is. Igyekeztünk a részt vevő diákokat megismertetni a laboratóriumban történő szakszerü, fegyelmezett viselkedésre és munkára, a védőfelszerelések szakszerü használatára, a munka- és balesetvédelmi előírásokra és ezek betartására. Ennek alapvető jelentősége van a labormunka közben óhatatlanul fellépő veszélyforrásokból fakadó balesetek elkerülésében.

4. A témák központjában a problémafelvetés és problémamegoldás állt. Ezek megoldásához, magyarázatához tapasztalati úton, felfedezéssel jutottak el a gyerekek, melyben nagy jelentőséggel bírtak az előzetes tapasztalatokból származó hipotézisek. Így gyakori volt, hogy az eredetileg tervezett kísérletek kiegészültek a gyermekek által felvetett ötletek kipróbálásával.

5. Mindvégig alapvető szempont volt, hogy a gyerekek aktív résztvevőként és ne csak passzív szemlélőként, megfigyelőként, segítőként vegyenek részt a tevékenységekben, hiszen ezzel növeljük önállóságukat, emellett segítjük a tapasztalatok beépülését a meglévő ismeretrendszerbe, melyek ezáltal könnyebben előhívhatóvá válnak a hétköznapi jelenségek magyarázata és a problémák megoldása során.

6. A közösen, párban és kiscsoportban végzett tevékenységek során arra is hangsúlyt fektettünk, a diákok ismerjék fel, hogy felelösséggel tartoznak társaikért, emellett az együttmüködés munkájuk minőségét, pontosságát és mások eredményességét is befolyásolja. Nem utolsósorban a közös munka során egymást segítve és kiegészítve hajtották végre feladatukat, mely a szociális érzékenységüket is fejlesztette.

7. A tapasztalatok részletes megbeszélése és rögzítése sem maradhatott el, hiszen ez segítette a hatékonyabb megértést és rögzülést, valamint az algoritmikus gondolkodás kialakulását.

8. Minden szakköri óra végén értékeltük az eredményeinket és a munka minőségét. Emellett ekkor került sor a hosszabb időtartamot igénybe vevő kísérletek előkészítésére is (például kandiscukor készítése).

A szakkör tervezésének lépései:

- módszertani felkészülés: főbb témakörök és tevékenységek meghatározása, kapcsolása a tantervhez;

- időterv kialakítása, a tevékenységek ütemezésének tervezése;

- előzetes költségvetés készítése;

- szükséges anyagok és eszközök beszerzése;

- a szakkör meghirdetése (plakátok kihelyezése és az osztályok személyes megkeresése)

- lebonyolítás, a kísérletek elvégzése (két hetente 90 perces foglalkozások keretében). 


\section{Gyakorlati megvalósítás}

A feldolgozás során tematikus egységekben gondolkodtunk, melynek alapját a négy őselem jelentette. Ennek érdekében a szakkör ütemtervének elkészítésénél fontos szempont volt, hogy közel azonos időintervallumban foglalkozzunk az egyes elemekkel, valamint, hogy mindegyikhez a lehető leglátványosabb kísérleteket sorakoztassuk fel melyek egyaránt könnyen megvalósíthatóak és illeszkednek a gyerekek életkori sajátosságaihoz, előzetes tudásához és képességszintjéhez. Mivel nem titkolt célunk volt, hogy a természettudományos nevelést támogassuk, a Nemzeti Alaptanterv tanulási eredményeit is számba vettük, melyeket érhetjük el a tevékenységek során a tanulókkal (NAT, 2020).

Az 1. táblázat a szakkör ütemtervét mutatja. A táblázatban a témakörökhöz tartozó néhány fontosabb kísérlet kerül felsorolásra. Az októberi tevékenységek végzését megelőzte a labor bemutatása, a kísérleti eszközök megismerése, valamint a helyiség és az eszközök balesetmentes használatához kötődő szabályok megbeszélése.

1. táblázat

Szakköri ütemterv - Forrás: Bauer Zita és Papik Eszter (2019)

\begin{tabular}{|c|c|c|c|}
\hline idő & $\begin{array}{l}\text { téma- } \\
\text { körök }\end{array}$ & kísérletek & tanulási eredmény \\
\hline $\begin{array}{l}\text { október- } \\
\text { november }\end{array}$ & tüz & $\begin{array}{l}\text { - } \quad \text { vulkán készítése } \\
\text { oszlop mögötti } \\
\text { tűz: miért nem } \\
\text { véd meg a széltől } \\
\text { a hirdetőoszlop? } \\
\text { az égés feltételei- } \\
\text { nek vizsgálata }\end{array}$ & $\begin{array}{l}\text { Tanítói segítséggel égéssel kapcsolatos } \\
\text { egyszerủ kísérleteket végez, csoporto- } \\
\text { sítja a megvizsgált éghető és éghetetlen } \\
\text { anyagokat. } \\
\text { Figyelemmel kísér rövidebb-hosszabb } \\
\text { ideig tartó folyamatokat (például olva- } \\
\text { dás, forrás, fagyás, párolgás, lecsapódás, } \\
\text { égés, ütközés). } \\
\text { A tanító által felvetett problémákkal } \\
\text { kapcsolatosan hipotézist fogalmaz meg, } \\
\text { a vizsgálatok eredményét összeveti } \\
\text { hipotézisével. } \\
\text { Az adott kísérlethez választott eszközö- } \\
\text { ket megfelelően használja. }\end{array}$ \\
\hline
\end{tabular}




\begin{tabular}{|c|c|c|c|}
\hline $\begin{array}{l}\text { december- } \\
\text { január }\end{array}$ & levegő & $\begin{array}{l}\text { - a levegő anyag } \\
\text { voltának kimu- } \\
\text { tatása: mi van az } \\
\text { üres pohárban? } \\
\text { a szél: lufik közé } \\
\text { fújt levegő } \\
\text { mini forgószél } \\
\text { készítése konfet- } \\
\text { tikkel } \\
\text { tüdőkapacitás } \\
\text { mérése } \\
\text { a levegő nyomása: } \\
\text { pingponglabda- } \\
\text { tölcsér } \\
\text { lufirakéta készí- } \\
\text { tése } \\
\text { a levegő rezgése: } \\
\text { idomított papírga- } \\
\text { lacsinok } \\
\text { a levegő rezgése: } \\
\text { telefon készítése } \\
\text { fénytörési kísér- } \\
\text { letek: a fény tréfái } \\
\text { (optikai csalódá- } \\
\text { sok), szivárvány } \\
\text { készítése, titkos- } \\
\text { írás } \\
\text { fényképezőgép } \\
\text { készítése } \\
\text { rakéta (pezsgőtab- } \\
\text { letta) }\end{array}$ & $\begin{array}{l}\text { A tanuló adott szempontok alapján, } \\
\text { algoritmus szerint élettelen dolgokon } \\
\text { megfigyeléseket végez. } \\
\text { Felismeri az élettelen dolgokon az érzé- } \\
\text { kelhető tulajdonságokat. } \\
\text { Megfigyeléseinek, összehasonlításainak } \\
\text { és csoportosításainak tapasztalatait } \\
\text { szóban, rajzban, írásban rögzíti, megfo- } \\
\text { galmazza. } \\
\text { Figyelemmel kísér rövidebb-hosszabb } \\
\text { ideig tartó folyamatokat. } \\
\text { A tanító által felvetett problémákkal } \\
\text { kapcsolatosan hipotézist fogalmaz meg, } \\
\text { a vizsgálatok eredményét összeveti } \\
\text { hipotézisével. } \\
\text { Az adott kísérlethez választott eszközö- } \\
\text { ket megfelelően használja. }\end{array}$ \\
\hline $\begin{array}{l}\text { február- } \\
\text { március }\end{array}$ & víz & $\begin{array}{ll}\text { - } & \text { szökőkutak ké- } \\
\text { - } & \text { szítése } \\
\text { oldódásnapi parti: } \\
\text { tea, kakaó, szén- } \\
\text { savas limonádé } \\
\text { készítése } \\
\text { - } \quad \text { lávalámpa készí- } \\
\text { tése } \\
\text { - } \text { vízben nyíló pa- } \\
\text { pírvirágok } \\
\text { a növények víz- } \\
\text { - } \quad \text { kzállítása } \\
\text { kandiscukor ké- } \\
\text { - } \quad \text { szítése } \\
\text { - } \quad \text { úistálynövesztés } \\
\text { - } \quad \text { fénysuavak } \\
\text { - réteges víz }\end{array}$ & $\begin{array}{l}\text { Figyelemmel kísér rövidebb-hosszabb } \\
\text { ideig tartó folyamatokat (például olva- } \\
\text { dás, forrás, fagyás, párolgás, lecsapódás, } \\
\text { égés, ütközés). } \\
\text { Egyszerű kísérletek során megfigyeli } \\
\text { a halmazállapot-változásokat: fagyás, } \\
\text { olvadás, forrás, párolgás, lecsapódás. } \\
\text { Azonosítja az anyagok halmazállapotait, } \\
\text { megnevezi és összehasonlítja azok alap- } \\
\text { vető jellemzőit. }\end{array}$ \\
\hline
\end{tabular}




\begin{tabular}{|c|c|c|c|}
\hline $\begin{array}{l}\text { április- } \\
\text { május }\end{array}$ & föld & $\begin{array}{ll}\text { - } & \text { kísérletek tojással: } \\
\text { nyers, vagy főtt } \\
\text { tojás? } \\
\text { kísérletek tojással: } \\
\text { mésztartalom } \\
\text { kimutatása } \\
\text { kísérletek a mág- } \\
\text { nessel: mágneses } \\
\text { mező vizsgálatai } \\
\text { kísérletek a mág- } \\
\text { nessel: a mágnes } \\
\text { erősségének meg- } \\
\text { figyelése, } \\
\text { kísérletek a mág- } \\
\text { nessel: mágneses } \\
\text { pólusok (játék) } \\
\text { mágnesezhetőség: } \\
\text { tű átmágnesezé- } \\
\text { se, mágnesesség } \\
\text { megszüntetése } \\
\text { iránytű készítése } \\
\text { iskolakert: a növé- } \\
\text { nyek csírázásának, } \\
\text { növekedésének } \\
\text { vizsgálatai }\end{array}$ & $\begin{array}{l}\text { Adott szempontok alapján képes élőlé- } \\
\text { nyeket összehasonlítani, csoportosítani. } \\
\text { Felismeri az élőlényeken, élettelen } \\
\text { anyagokon az érzékelhető, mérhető és } \\
\text { a kölcsönhatásokban megnyilvánuló } \\
\text { tulajdonságokat. } \\
\text { Az adott kísérlethez választott eszközö- } \\
\text { ket megfelelően használja. } \\
\text { Összehasonlítja az élőlényeket és az } \\
\text { élettelen anyagokat. } \\
\text { Felelősségtudattal rendelkezik a szű- } \\
\text { kebb, illetve tágabb környezete iránt. } \\
\text { Felismeri a lakóhelyéhez közeli életkö- } \\
\text { zösségek és az ott élő élőlények közötti } \\
\text { különbségeket (pl. természetes - mes- } \\
\text { terséges életközösség, erdő - mező, rét } \\
\text { - víz, vízpart - park, díszkert - zöldsé- } \\
\text { ges, gyümölcsöskert esetében). } \\
\text { Felismeri és megérti, hogy az élhető } \\
\text { jövő záloga a környezettudatos, fenn- } \\
\text { tarthatóságot szem elött tartó gondol- } \\
\text { kodás. } \\
\text { A természetben lejátszódó folyamatok } \\
\text { vizsgálatával, a várható következmé- } \\
\text { nyek megértésével cselekvőképes, a } \\
\text { környezetért felelősséggel tenni akaró } \\
\text { állampolgárrá váljon, ezzel is hangsú- } \\
\text { lyozva, hogy az ember egyénként és egy } \\
\text { nagyobb közösség részeként egyaránt } \\
\text { felelős természeti környezetéért, annak } \\
\text { jövőbeni állapotáért. }\end{array}$ \\
\hline
\end{tabular}




\section{A gyerekek kedvenc kísérleteinek bemutatása}

A továbbiakban a víz témakörből választottunk ki és mutatunk be két olyan kísérletet, mely a víz témakörben a gyermekek tetszését leginkább elnyerte.

\section{Szivárványhid készitése}

A kísérlet tartalma: A víz szállításának és a színek keveredésének megfigyelése.

Eszközök:

- papírtörlő

- három átlátszó pohár

- különböző színű ételfestékek, vagy tinták (ugyanannyi minden pohárba)

- víz

A kísérlet menete: Kiválasztjuk a keverni kívánt színeket. (A vörös és a sárga, a kék és a sárga, valamint a piros és a kék színpárok a leglátványosabbak.) Minden színhez külön edénybe töltünk vizet, majd hozzáadjuk az ételfestéket. Szükség van egy további üres pohárra minden színpárhoz. A poharakat sorba állítjuk, úgy, hogy az üres kerül középre. A gyermekek megfigyelik a két folyadék érzékelhető tulajdonságait, különös tekintettel a színre, majd rajzban rögzítik a kiinduló állapotról szerzett tapasztalataikat.

Előkészítünk egy harmadik poharat. Feltekerünk egy papír törlőkendőt, majd megbeszéljük a tanulókkal a kísérlet menetét. Ezután a gyermekek megfogalmazzák hipotéziseiket a következő kérdések alapján: Mit gondoltok, mit fogunk tapasztalni, ha elvégezzük a kísérletet? Mi lesz a középső pohárban a kísérlet végén?

A hengerelt papírtörlő egyik végét az egyik vizes pohárba, a másik felét pedig a középen lévő üres pohárba helyezzük. Ezután egy újabb papírtörlőt tekerünk fel, melynek egyik végét a másik színes vízzel töltött pohárba helyezzük, másik végét pedig szintén a középső, üres pohárba. (Ha igazi szivárványhidat szeretnénk készíteni, több pohárral és színnel is elvégezhetjük a tevékenységet.)

A kísérlet közben pár percenként, illetve a végén a tanulók megfigyelik a változást. Rajzos feljegyzést készítenek a befejező állapotról, majd ezt összehasonlítják a kiinduló állapottal.

Megfigyeléseik tapasztalatát a következő kérdések alapján megbeszéljük, majd rövid magyarázatot adunk a folyamatra.

- A várt eredményre jutottunk?

- Mi történt az eredeti poharakban lévő vízzel?

- Milyen változást láttunk a papírtörlőkön?

- Mit tapasztaltunk a középső pohárban?

- Milyen színü vizet láthatunk ebben a pohárban? Mit gondoltok, mi lehet ennek a magyarázata? 
Tapasztalat: A színes víz rövid idő múlva elkezd felfelé haladni a papírtörlőkön, majd végighaladva azokon megtölti az üres poharat. Ekkor a két szín keveredését is jól láthatjuk. A vándorlás addig tart, míg mindhárom pohárban egyforma mennyiségü víz nem lesz. (1. és 2. kép)

Magyarázat: A papírtörlők felszívják a színes vizet, így elszíneződnek. A „hidak" átvezetik a külső poharakból a színeket a középsőbe, így ott összekeverednek és megjelenik egy új, kevert szín. (Jelen kísérletben ez az úgynevezett másodlagos szín a zöld lett.)

Alkalmazás: Hol találkozunk ezzel a jelenséggel a mindennapokban? (például színkeverés)
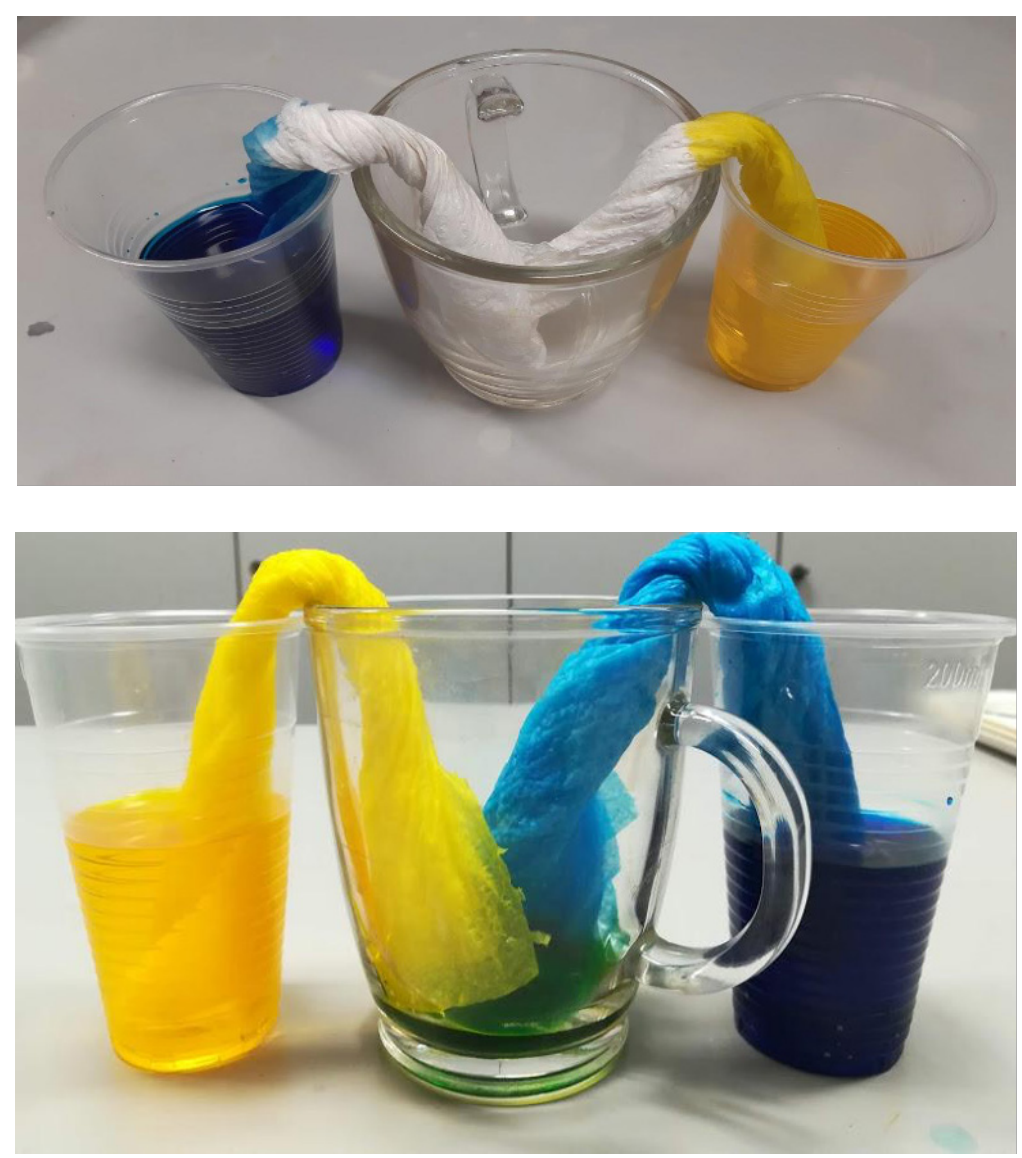

1-2. kép

Szivárványhíd 


\section{Növények vízszállitásának megfigyelése}

A kísérlet tartalma: A növények táplálkozásának, a víz felszívásának és a száron keresztül a növény többi részébe való eljutásának (vízszállítás) megfigyelése.

Eszközök:

- egy szál fehér színű rózsa (zellerszárral, szegfüvel is el lehet végezni a kísérletet)

- két müanyag pohár

- piros és kék ételfesték vagy tinta

- víz

- egy kanál (keveréshez)

- kés

A kísérlet menete: Két üvegpoharat félig megtöltünk vízzel. Az egyikbe piros, a másikba kék festéket öntünk (érdemes jó sötétre színezni). Mindkettőt megkeverjük. Hosszában a rózsa szárát annak feléig kettévágjuk.

A növényt úgy állítjuk a festékekbe, hogy a szár egyik felét a piros, a másikat a kék festékbe tesszük.

A gyermekek megfigyelik a növény érzékelhető tulajdonságait, különös tekintettel a színre, majd rajzban rögzítik a kiinduló állapotról szerzett tapasztalataikat. A kísérlet menetének megbeszélése után a gyermekek megfogalmazzák hipotéziseiket az alábbi kérdések mentén:

Mit gondoltok, mit fogunk tapasztalni, ha elvégezzük a kísérletet? Mi fog szerintetek megváltozni?

Várunk néhány órát, vagy akár egy egész napot.

A kísérlet közben, illetve végén a gyermekek megfigyelik a változást.

A tanulók rajzos feljegyzést készítenek a befejező állapotról is, majd öszszehasonlítják a kiinduló állapottal. Megfigyeléseik tapasztalatát a következő kérdések mentén megbeszéljük, majd rövid magyarázatot adunk a folyamatra.

- A várt eredményre jutottunk?

- Milyen színűek lettek a növény virágának szirmai?

- Mit gondoltok, miért?

Tapasztalat: Az eredetileg fehér színű virág egyik felén kék színüre festődtek a szirmok, másik felén pirosra. (3. 4. és 5. kép)

Magyarázat: A növény szárában lévő szállító csöveken keresztül a felvett színes víz elszállítódik a levelekbe és a virágokba, amiket megfest.

Alkalmazás: A víz növények életében való szerepének és a vízszállítás jelentőségének megbeszélése. 

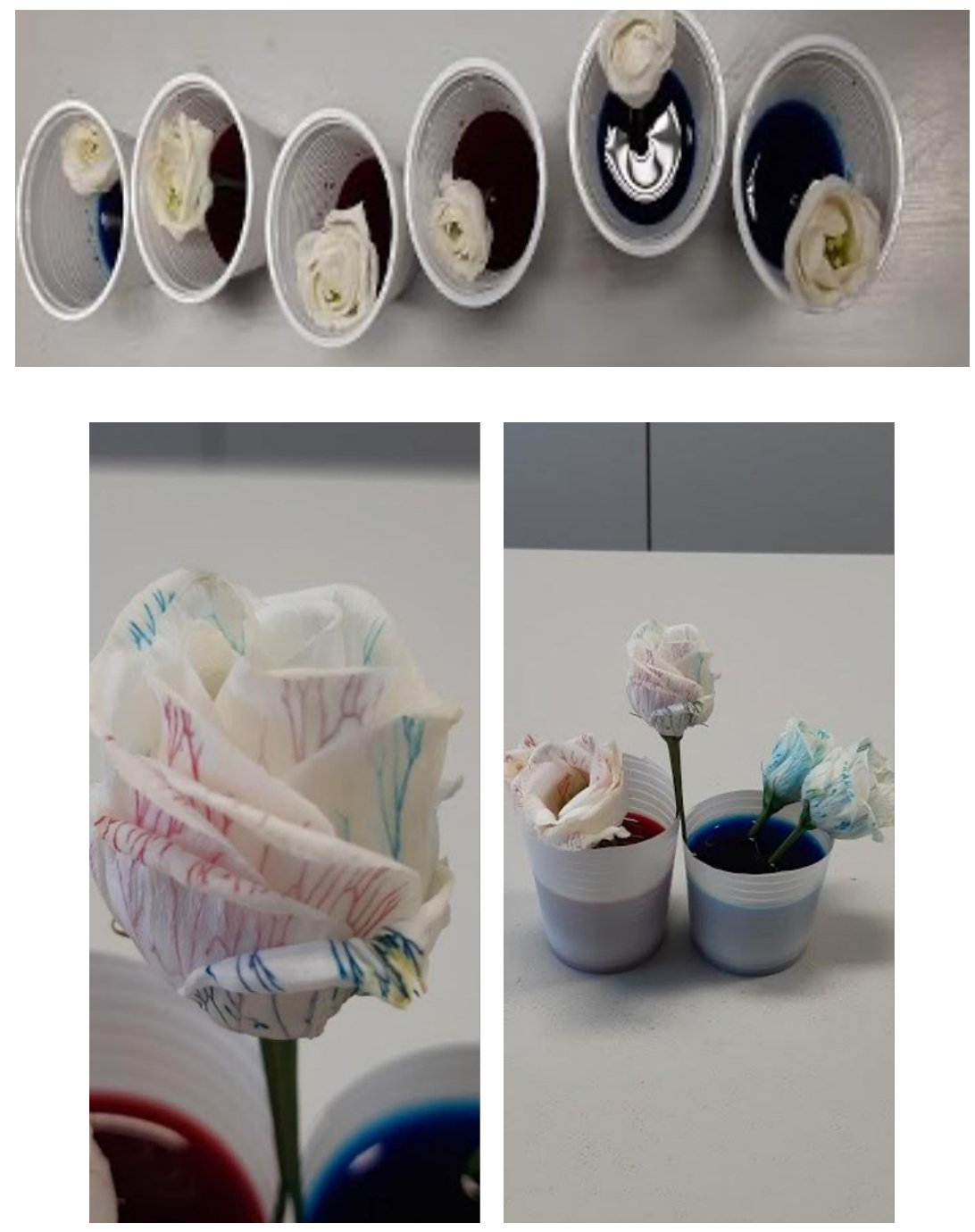

3-5. kép

Virágszirom festése 


\section{A szakkör tapasztalatai, elért eredmények}

A szakkör folyamán a kísérletek elvégzése által a gyerekekkel az alábbi tanulási eredményeket mindenképpen elértük:

- A kísérletek tapasztalatait a mindennapi életben alkalmazni tudták.

- A vizsgálatok tapasztalatait megfogalmazták, rajzban, írásban rögzítették.

- Az adott kísérlethez választott eszközöket megfelelően tudták használni.

- A kísérletezés elemi lépéseit annak algoritmusa szerint megvalósították.

- Tanítói segítséggel egyszerủ kísérleteket végeztek.

- Képessé váltak az önálló ismeretszerzésre, az összefüggések felismerésére és az egyszerű elemzések elvégzésére a tanulói kísérletek, megfigyelések és vizsgálatok révén (NAT, 2020).

A természettudományos célok elérése mellett fontos eredmény, hogy a gyerekek a tevékenységek során kiválóan müködtek együtt. Tekintve, hogy csak két hetente voltak a foglalkozások és a gyerekek különböző évfolyamról és osztályból jelentkeztek, ez még nagyobb eredmény ilyen rövid idő alatt. Más szakkörökön észlelhetőek voltak kisebb-nagyobb konfliktushelyzetek, azonban nálunk, valószínűleg a kísérletek jellegéből adódó szabálykövetésnek, fókuszált figyelemnek és szoros együttmüködésnek köszönhetően nem jelentek meg ezek. A félév közeledtével az is nyilvánvalóvá vált, hogy a gyerekeknek természetessé vált az eszközhasználat, melyet sokszor, ha volt rá lehetőség, otthon is alkalmaztak egy-egy kísérlet újraalkotása során. Két alkalom között rendszeresen kaptunk információt arról, hogy mely kísérletet végeztek el otthon újra, vagy érdeklődve kerestek meg minket, hogy mi lesz a következő alkalommal. Lelkesedésük mindvégig töretlen volt. Tapasztalataink azt mutatják, hogy kitüzött céljaink megvalósultak, hiszen a gyerekek nem csak környezetismeret tantárgyhoz kapcsolódó fogalmakat értettek meg mélyebben (például oldódás), hanem rendkívül motiváltak lettek a természettudományokkal kapcsolatban, attitüdjük pozitívan változott, mely a további fenntartható szemlélet kialakításához is elengedhetetlen.

\section{Irodalom}

Gaál G. \& Jászi É. (2015). Pedagógus-mesterség. Líceum Kiadó.

Jenei P., Enreiter Á., Juhász A. \& Nagy M. (2011). Kísérletek a hullámokkal In Tasnádi P. (Ed.), Természettudomány tanitása (pp. 79-85). ELTE Természettudományi Kar.

Nemzeti Alaptanterv. Magyar Közlöny https://magyarkozlony.hu/dokumentumok/ 3288b6548a740b9c8daf918a399a0bed1985db0f/ (2020.09.06.)

Papp K. (2014). Motiváció a természettudományos nevelés során. In Radnóti K.

(Ed.), A természettudományok tanítása. Szakmódszertani tankönyv és kézikönyv (pp. 420-421). Mozaik Kiadó.

Tóthné T. I. (2015). Szakköri segédlet KÉMIA 7-8. évfolyam. József Attila Gimnázium, Szakközépiskola és Kollégium. 


\section{Bauer, Z. \& Papik, E.}

\section{The possibilities of science education in professional circles}

Experimental techniques are of paramount importance in the experiential teaching and learning of natural sciences. In addition to developing cognitive skills, they inspire or increase students' interest in nature and science, motivate learning, promote the development of scientific and problem-solving thinking, help form their work habits, and contribute to the strengthening of their social competencies. In addition to getting to know the environment, the activities help to develop an ecological and systems approach, as well as positive attitudes towards the environment, which are important foundations for the implementation of the pedagogical content of sustainability. Extracurricular activities, including professional groups, can be important tools to help achieve these goals. In our study, we present the contents and results of a professional group implemented with third and fourth grade children. We propose the topics of the sessions - the simple but spectacular activities carried out - to the prospective teachers engaged in age-appropriate activities likely to arouse the children's interest. It is our aim in this article to help not only those planning a professional session, as these experiments can be well integrated into the system of activities carried out during the lessons.

Keywords: science education, scientific thinking, experiment, profession, attitude 